\title{
The human spirit as a necessary condition for higher education:
}

\section{a risk assessment}

\author{
JS WESSELS ${ }^{1}$ \\ ... to engage practically in the awkward, \\ messy, joyful, and risky work of thinking and \\ acting differently in seemingly frozen states of \\ domination
}

(Amsler 2011:81)

\begin{abstract}
Risk management can either protect or endanger higher education institutions (HEIs) in South Africa. A crucial determining factor is how the core risks for these institutions are identified and mitigated. This article contributes to the continuing discourse on both risk management and managerialism in higher education. The thesis for this article is that the presence of a caring human spirit within HEIs is a necessary condition for them to fulfil their reason for existence. The purpose of this article is thus to reflect on the risk of HEIs not being able to fulfil their fundamental reason for existence due to the smothering or absence of a caring human spirit in these institutions. A reading of official and scholarly texts has shown that HEIs' primary reason for existence is embedded risk, namely a concern with the new or the unknown and by implication a critical curiosity about an uncertain future. The presence of a caring human spirit is not only a necessary condition for fulfilling the reason for the existence of an HEI, but also a crucial risk category currently absent from the standard list of institutional risk categories. Risk assessment reveals that the absence or smothering of a caring human spirit in HEIs poses a high to very high risk for their survival.
\end{abstract}

Key words: Higher education; risk management; managerialism; human spirit; care; science.

\section{Introduction}

Risk management can either protect or endanger higher education institutions (HEIs) in South Africa. A crucial determining factor is how the core risks for these institutions are identified and mitigated. This article argues that, because HEIs are expected to be the dominant contributors to "new knowledge", "new applications for existing knowledge" and opportunities for "social mobility" according to the White paper for post-school education and training (South Africa 2013:27). The core risk to HEIs is the loss of what can be regarded as the necessary condition for their survival and flourishing, namely the presence of a caring human spirit. Within the South African context, De Beer (1991:106-112) introduced this

1. Professor JS Wessels is research professor in the Department of Public Administration and Management at Unisa. E-mail: wessejs@unisa.ac.za

$2 \quad$ Noteworthy in this regard are the following: Meeting the Challenges of Enterprise Risk Management in Higher Education (Association of Governing Boards of Universities and Colleges [AGB] 2007); The State of Enterprise Risk Management at Colleges and Universities Today (AGB 2009); URMIA White Paper: ERM in Higher Education (Morris 2007); Road to implementation: Enterprise Risk 
discourse by referring to the absence of the human spirit in the practice of science, as a crisis and by implication as a risk.

Risks, risk assessment and risk management are not only topical themes for scholarly discourse in the social, management and accounting sciences, but have increasingly become integrated into the concerns and activities of practitioners within public and private organisations. HEIs worldwide, but also in South Africa have not escaped the obligation to comply with the regulatory requirements pertaining to enterprise risk management.

Various voices have participated in the scholarly discourse on risks, risk assessment and risk management (Adam 1998; Adams 1995; Beck 1992; Beck 2000; Dupuy 2008). The intensity of these discourses has increased after the publication of the ISO 31000:2009 as the internationally accepted standard for enterprise risk management by the International Standard Organisation (ISO) in 2009 (Andretta 2014; Aven 2012; Leitch 2010; Purdy 2010; Scheer, Benighaus, Benighaus, Renn, Gold, Röder \& Böl 2014; Tufano 2011). With regard to risk management within HEIs, Tufano (2011:58) in his article "Managing risk in higher education" argues that these institutions' risk management frameworks should be aligned to their reason for existence. This implies that risk management should be “... missioncentered, strategic, and broad enough to capture those issues that are of fundamental importance to the ongoing success and mission of the institution" Tufano (2011:58). Considering their reasons for existence and the related embedded risks, Tufano (2011:54, 56-57) raises the question whether HEIs' risk management frameworks are not "too timid regarding risks". Being inclined to over-regulation in an effort to mitigate or prevent risks, these institutions are therefore potentially exposed to the smothering of the human spirit, embodied by the decline in academics' critical, investigative and risk-taking inclination. The human spirit seems to be vital for exploring the uncertain and the unknown which characterises HEIs' expected contribution to new knowledge, new knowledge applications and social mobility (South Africa 2013:27).

The fundamental reason for the existence of universities thus seems to be embedded in their role as the sites and agents for the discovery, understanding and transmission of both existing and new knowledge. As eloquently argued by Stiegler (2010:107-112; 177-184) in his book Taking care of youth and the generations, the presence of a caring human spirit is therefore indispensable for HEIs. He refers to the caring human spirit as one that seeks to understand, to demystify, to transform, to educate, to pay attention, and to enhance movement (Stiegler 2010:107-112; 177-180). This movement relates directly with the concept "social mobility" as used in the White Paper for post school education and training (South Africa 2013:27). The presence of a caring human spirit has been shown to be threatened by the creeping culture of managerialism in higher education (Davis, Jansen van Rensburg \& Venter 2014; McWilliam 2007:311-328; Weinberg \& Graham-Smith 2012:68-86), specifically as it causes a culture of conformance "at the cost of innovation and experimentation" (Davis et al. 2014). Such a culture of conformance may be seen as a symptom of a smothered human spirit.

This article aims at contributing to the existing discourses on both risk management and higher education by reflecting on the risk that smothering the human spirit may result in higher education institutions not fulfilling their reason for existence. The reflection will unfold through an argument departing from the premise that the primary reason for the existence of HEIs is a concern with and a movement towards the new, the unknown and an uncertain future. The second and equally fundamental departing premise is that a caring human spirit is a necessary condition for such a concern. The logical conclusion of this 
argument is that a caring human spirit is a necessary condition for the HEIs to fulfil their reason for existence. Considering that institutional risk management should focus on what is important for the accomplishment of an institution's mission (Tufano 2011:58), this conclusion will be validated by assessing the risk (the likelihood and consequence) to HEIs of a smothered caring human spirit. As this article is primarily contextualised within the discourse of enterprise risk management within HEIs, its point of departure is a reflection on risk and risk management.

\section{Risk and risk management}

As indicated in the introduction, the discourse and related concepts on risk and risk management are not new. In fact, various scholars have contributed to this enduring discourse during the last twenty years. The work of Beck $(1992 ; 2000)$ on the risk society can be regarded as seminal in this discourse. Equally significant is work by Adams (1995), Adam (1998), Adam and Van Loon (2000), and Tufano (2011). The latter has not only highlighted the politics and sub-politics of risk definition, but also the evolving of a particular mode of organisation entailing a sense of institutional domination, as revealed by Adam and Van Loon (2000:4-5).

Lash (2000), by responding to Beck's (2000) notion of the risk society, has suggested that the risk society may instil a risk culture, recognised for its diversity of risk-related practices. The existence of a risk culture thus represents not only an understanding of risk, but also a pragmatic and responsive concern for the future by actualising desired possibilities resulting in risk management practices aimed at the eventual "risk displacement" (Adam \& Van Loon 2000:13).

Subsequently, the need for standards and guidelines for risk management aimed at risk displacement has featured on the agendas of various influential institutions and think tanks (e.g. Association of Governing Boards of Universities and Colleges [AGB] 2007). These deliberations have culminated in several reflective reports on enterprise risk management, especially applicable to the higher education sector. ${ }^{2} \mathrm{~A}$ variety of standard-setting practices to enterprise risk management followed, ${ }^{3}$ of which the King Code of Governance for South Africa (2009) and the standard by the International Standards Organisation (ISO) are perhaps the most influential guidelines for risk management. The publication of the ISO 31000:2009 standard for risk management published in 2009 (Leitch 2010), lead to a vibrant critical discourse on the general principles and practices of standard setting, as well as on this particular standard for risk management (Andretta 2014; Aven 2012; Leitch 2010; Purdy 2010; Scheer et al. 2014; Tufano 2011; Aven 2012; Andretta 2014; Scheer et al 2014).

Noteworthy in this regard are the following: Meeting the Challenges of Enterprise Risk Management in Higher Education (Association of Governing Boards of Universities and Colleges [AGB] 2007); The State of Enterprise Risk Management at Colleges and Universities Today (AGB 2009); URMIA White Paper: ERM in Higher Education (Morris 2007); Road to implementation: Enterprise Risk Management for Colleges and Universities (Gallagher 2009).

Examples: Committee of Sponsoring Organisations (also known as COSO); The Australia/New Zealand Standard for Risk Management; The Combined Code and Turnbull Guidance: The Risk Management Standard by the Federation of European Risk Management Associations (FERMA); The International Organization for Standardization (ISO); The Sound risk governance practices (Financial Stability Board 2013); Risk Management and Corporate Governance" (Organisation for Economic Co-operation and Development (OECD0 (2014). 
In order to understand fully the risk-related concepts (risk society, risk culture, risk displacement and risk management) that have emerged in the course of the discourse to be reviewed in this section, conceptual clarity about the key concept 'risk' is necessary. Although various scholars have contributed to the rich and nuanced meaning of the concept (Adams 1995; Adam 1998; Adam \& Van Loon 2000; Beck 1992; 2000), the current discussion will revert to only the following few as they have specifically set out to analyse and consider the various nuances. According to Douglas (1992:46), 'risk' is "not a thing” but "a way of thinking”. Beck (2000:213) views risk as a “... peculiar, intermediate state between security and destruction, where the perception of threatening risks determines thought and action". He elaborates on his view of this "intermediate state" as a state reversing "the relationship of past, present and future" resulting in the past losing "its power to determine the present" to the future, which is "something non-existent, constructed and fictitious" (Beck 2000:214). It seems that Beck regards risk as being the power of a non-existent, constructed and fictitious future in determining the present. Dupuy (2008:4) appears to hold a different view from Beck (2000) on the effect of a fictitious future on the present by arguing, "[if] the future is not real, it is not something that projects its shadow onto the present ... If the future is not real, there is nothing in it that we should fear, or hope for."

Dupuy's argument needs to be understood against the backdrop of his differentiation between known risks and hypothetical (fictitious) risks (Dupuy 2008:5). He argues that a known risk can be quantified "in terms of objective probabilities based on observable frequencies" while hypothetical risks are those non-quantifiable risks resulting from our inability to "properly gauge the type of uncertainty with which we are confronted at present" (Dupuy 2008:5). The latter category of risks signifies the point where "one enters the realm of uncertainty" (Dupuy 2008:5). Known risks (although still meeting the criteria of a "non-existent, constructed and fictitious future") endangering the achievement of an institution's objectives are classified as being of a strategic, financial, operational, compliance or reputational nature (Morris 2007:5). Whether these risks are completely outside the realm of uncertainty as suggested by Dupuy, is doubtful. Therefore, the definition of risk by the working group formulating the ISO 3100:2009 standard as being the "effect of uncertainty on objectives" (Purdy 2010:882) may serve as an acceptable working definition. The definition of risk in the South African King III report is more or less the same, since it refers to risks as being "uncertain future events that could influence, both in a negative and a positive manner, the achievement of the company's objectives" (King III 2009:56). Within the context of the argument developed in this article, the concept 'risk' thus refers to those uncertain future events that may influence HEIs' present strategies (see the above reference to Beck's (2000:213) notion 'thought'), plans and actions (see the above reference to Beck's (2000:213) notion 'action') for achieving their primary reason for existence.

\section{Primary reason for existence of HEIs}

Crucial for the further development of this argument is the identification of the primary reason for the existence of HEIs, which distinguishes HEIs from other, similar institutions. I have deliberately not reverted to the rich and abundant scholarly discourse on higher education as a point of departure. As a Public Administration scholar, I have traced South African HEIs' reasons for existence by reading a collection of official documents on higher education recently published by a variety of South African government institutions. These documents include, the White paper for post-school education and training: Building an expanded, effective and integrated post-school system (South Africa 2013), the South African 
Higher Education in the 20th Year of Democracy: Context, Achievements and Key Challenges (South Africa 2014), and A proposal for undergraduate curriculum reform in South Africa: The case for a flexible curriculum structure (Council on Higher Education [CHE] 2013).

For the purpose of the argument, I have scrutinised these texts for authoritative indications on what is officially regarded as the reason for the existence of HEIs in South Africa. Consequently, I have applied primarily the reproductive (literally) reading modality accepting the authority, superiority and adequacy of these texts (De Beer 2014:211) for determining an as near as possible official indication of the reason for existence of these institutions. I have done that, irrespective of known limitations (e.g. the non-obviousness of the supposed obviousness of the foundations of these documents) of the use of these documents (Roux \& De Beer 2014:98). The results of this reading process are summarised in Table 1.

Table 1: Summary of key concepts indicating the reasons for existence of HEIs

\begin{tabular}{|l|l|}
\hline Selected text & $\begin{array}{l}\text { Key concepts indicating the reason for } \\
\text { existence of HEIs }\end{array}$ \\
\hline $\begin{array}{l}\text { National Development Plan (National } \\
\text { Planning Commission 2011) }\end{array}$ & $\begin{array}{l}\text { "unique contribution towards knowledge } \\
\text { production and national development" } \\
\text { (National Planning Commission 2011:267) } \\
\text { "promotion of innovation and the } \\
\text { development of knowledge" (2011:267) }\end{array}$ \\
$\begin{array}{l}\text { White paper for post-school education and } \\
\text { training: Building an expanded, effective and } \\
\text { integrated post-school system (South Africa } \\
\text { 2013) }\end{array}$ & $\begin{array}{l}\text { knowledge and skills required by the economy } \\
\text { developing thinking citizens, who can } \\
\text { function effectively, creatively and ethically as } \\
\text { part of a democratic society (South Africa } \\
\text { 2013:viii) } \\
\text { new knowledge } \\
\text { new applications of existing knowledge } \\
\text { social mobility (South Africa 2013:27) }\end{array}$ \\
\hline $\begin{array}{l}\text { A proposal for undergraduate curriculum } \\
\text { reform in South Africa: The case for a } \\
\text { flexible curriculum structure (CHE 2013) }\end{array}$ & $\begin{array}{l}\text { development of academic competencies and } \\
\text { attitudes that underpin advanced study and } \\
\text { critical thinking } \\
\text { being responsive to the needs of individual } \\
\text { citizens and of employers in both public and } \\
\text { private sectors } \\
\text { being responsive to broader societal and } \\
\text { developmental objectives (CHE 2013:96) }\end{array}$ \\
\hline $\begin{array}{l}\text { South African Higher Education in the 20th } \\
\text { Year of Democracy: Context, Achievements } \\
\text { and Key Challenges (South Africa 2014) }\end{array}$ & $\begin{array}{l}\text { a rigorous theorisation and scholarship on } \\
\text { teaching and learning } \\
\text { enhancing the learning and teaching } \\
\text { capabilities of academics and universities } \\
\text { (South Africa 2014:4) } \\
\text { high quality graduates and knowledge } \\
\text { new generations of outstanding scholars who } \\
\text { are committed to critical and independent } \\
\text { scholarship and social justice } \\
\text { epistemological transformations (South } \\
\text { Africa 2014:8) }\end{array}$ \\
\hline
\end{tabular}

TD, 11(2), November 2015, Special edition, pp. 13-28. 
The reading of the selected four texts revealed an agreement that the primary reason for the existence of HEIs consists of their three-dimensional engagement with knowledge, namely the "what", the "how" and the "why" of knowledge. The emphasis of the "what" dimension is on new knowledge, new applications of existing knowledge, and transformed theories of knowledge. The "how" dimension relates to distinct abilities of academic staff members (their ways of engaging with knowledge), such as critical and independent thinking, as well as ethical and transparent scholarship. The "why" dimension of their engagement may result in developing, changing and mobilising society at large through scholarly (the "what" and the "how") informed learning, teaching and engagement. It is evident from these documents that it is officially expected from South African HEIs, as part of the diverse spectrum of providers of education, to take sole responsibility for advanced thinking, teaching and learning through a commitment "to advancing learning" (Tufano 2011:57). These expectations not only imply the development, progress and improvement of knowledge, but also a focus on the future, whether known or hypothetical (Dupuy 2007/2008: 5). These official expectations furthermore resonate strongly with Amsler's (2011) views about the mission of universities as eloquently expressed in her passionate contribution "Beyond all reason: Spaces of hope in the struggle for England's universities", namely that universities need "to engage practically in the awkward, messy, joyful, and risky work of thinking and acting differently" (Amsler 2011:81). However, I share the concern of Roux and De Beer (2014:98) about the danger of the acceptance of the actions necessary for good science in HEIs as obvious or self-evident.

For the purpose of a second premise for this evolving argument, I consequently propose that HEIs' primary reason for existence is to be concerned with the new and the unknown and by implication to have a critical curiosity about an uncertain future.

\section{A caring human spirit: a necessity for HEIs fulfilling their reason for existence}

Following the above premise about the reason for the existence of HEIs, one may ask whether achieving these attributes is possible without the involvement of not only human beings, but also specifically the "human spirit"? By using the concept "necessary condition", I follow the standard definitions of this concept by proposing that a caring human spirit is a prerequisite for HEIs to fulfil their reason for existence. When using the concept "spirit" as a qualifier for the concept "human", I attach the same meaning to it as De Beer (2013:498). De Beer (2013:498) refers to "spirit" as the "organizing, fundamental and forceful principle that guides and inspires humans towards many great achievements", a principle "responsible for organising all special attributes and qualities of humans such as ... science, art and religion" and characterised by "human attitudes of friendship, love and care" (De Beer 2013:498).

The reading of the four texts revealed that the South African government indeed regards the "quality improvement and the development" of the academic staff as a "crucial factor" for HEIs (South Africa 2013:36). One can interpret this as government's acknowledgement that in order for academic staff members to be guided and inspired towards "many great achievements" (De Beer 2013:498), they at least need to be adequately qualified. Therefore, academic staff seems to plan for "a National Programme to develop the Next Generation of Academics for South African Higher Education” (South Africa 2013:60). On 5 March 2014, HESA also emphasised improvement of the qualifications of academic staff members as a priority during their presentation to the Portfolio Committee on Higher Education and Training. 
The emphasis on improved staff qualification emanates from HESA's concern about the fact that only $34 \%$ of academics in South African HEIs "have doctoral degrees, which is generally a prerequisite for undertaking high quality research and supervising doctoral students" (South Africa 2014:3-6). This lack of adequately qualified academic staff members indisputably contributes to the academic factors identified by the $\mathrm{CHE}$ as one of the three factors "affecting performance in higher education" (CHE 2013:55). From the reproductive reading of these four documents alone, it is evident that the South African government regards adequately qualified academics as a necessary condition for HEIs to contribute to (and perhaps also to care for) new knowledge and knowledge applications, to encounter the unknown and to confront the undetermined future critically. The attribute of being adequately qualified, for "many great achievements" (De Beer 2013:498) only partially comprises the full meaning of "spirit" within this context.

When Stiegler (2010:113) uses the concept “care", he uses it to refer to human involvement with the unknown and the future as "understanding and care". He furthermore refers to education as an "entirely other form of care" - a "metacare" (Stiegler 2010:177). The official documents' emphasis on the necessity of adequately qualified academics, thus implies an emphasis on caring as contextualised by Stiegler's view that "the truly educated learn to take care of themselves and thus others, in taking care of knowledge they have given, knowledge by which they can and must take care of the world" (Stiegler 2010:179). The relevance of Stiegler's words, as well as the expectations of the White Paper for Post-School Education and Training: Building an Expanded, Effective and Integrated Post-school System (South Africa 2013) that HEIs have to develop thinking citizens who can function effectively, creatively and ethically as part of a democratic society (South Africa 2013:viii), are confirmed by the following words of Castoriades (1984:145-146): "It is not stones or trees that matter to me, but men in the city". Castoriades thus means caring for what De Beer (1991:100) refers to as "essential issues leading to relevant science". By revisiting Table 1 and applying the hermeneutical reading modality (De Beer 2014:211) to the selected documents, the implications of the caring human spirit are evident from references to essential issues such as

- “social mobility” (South Africa 2013:63);

- developing of thinking citizens functioning effectively, creatively and ethically as part of a democratic society (South Africa 2013:viii);

- a responsiveness to the broader societal and developmental objectives (CHE 2013:96); and

- a deepening reflection on contextual issues (South Africa 2014:8).

For Stiegler (2010:179) "taking care" means to pay attention to and to maintain care of oneself, those close to one, and eventually everyone. De Beer (2013:498) refers in this regard to care as "the art of being". Caring within the context of HEIs is thus a spirited, cultural (human), and communal process of being a professional scholar by not only caring for the "what" of knowledge, but especially for the "how" and the "why". In this regard, Roux (2012:33-34) refers to the smothering effect of the pressure to publish on scholar's time to think, the opportunity to reason and even to reason oneself into a deadlock, and to participate in polemic discourses.

When I use the concept "human spirit" I thus refer to the characteristics (knowledge, habits and behaviour) of the adequately qualified, caring community of human beings (in this case, professional scholars), which are seemingly indispensable for the survival of HEIs. The question one may ask is whether this caring human spirit is at risk of being smothered or even 
of disappearance from the South African higher education sector? Furthermore, one may ask whether this risk is known, measurable and quantifiable, or whether it exists within the "realm of uncertainty" and consequently whether it is non-quantifiable and hypothetical (Dupuy 2008:5)?

A reflection on the caring human spirit at risk will not be complete without considering the effect on academics of the creeping culture of managerialism in HEIs. For the purpose of this article, I have selected only a few contributions to the rich and enduring discourse on managerialism and its subsequent legacy of conformance. All three of them relate in some way or another to the caring attribute of the human spirit. Weinberg and Graham-Smith (2012:68, 73-74) argue that the worldwide corporatisation of universities has resulted in the demise of collegiality - the scholarly community mentioned by De Beer (2013:498) - a trend undermining the "communitarian and independent spirit" foundational to the university (Weinberg and Graham-Smith 2012:68). It thus seems that the growing pressure on academic staff members to execute institutional operation plans and to meet quantifiable profitability targets constitutes a decrease in their ability to care for anything except complying with the institutional operational targets. This observation is supported by Davis et al.'s 2014 research on the "impact of managerialism on the strategy work of university middle managers" showing that managerialism "has resulted in a tyranny of bureaucracy which translates into disempowered middle managers, a culture of conformance over collegiality, control at the cost of innovation and experimentation and an over-articulation of strategy which devalues the strategy". It is specifically the over-articulation of the strategy to optimise the number of research output points for an HEI that concerns Roux (2012:34).

Related to the research by Davis et al (2014), is research regarding burnout of academic staff in South African HEIs by Rothmann and Barkhuizen (2008:439-456). This study has shown that "faculty burnout is a phenomenon of growing proportions", especially amongst younger (20-29 years) academics (Rothmann \& Barkhuizen 2008:441, 451, 452). This may be the result of a redirected and compliance-driven corporately managed care for maximising operational institutional targets (such as increased student throughput and higher numbers of accredited research output). The emphasis on performance evidently contributes to the demise of the human spirit in HEIs.

If one refers only to these three contributions, there seems not only to be support for the proposition that a caring human spirit is a prerequisite for HEIs to fulfil their mission, but a reasonable concern about the indication that the caring human spirit in HEIs is under siege. A state of being under siege does not imply a total absence of a caring human spirit in HEIs, but does suggest the presence of an actual (opposite to hypothetical) threat to the enduring presence of such a spirit. As a caring human spirit is evidently a necessary condition for the survival of HEIs, it is indeed a major risk to be properly considered, assessed and mitigated by the HEI sector.

\section{An assessment of the risk to HEIs of a smothered caring human spirit}

Considering that a caring human spirit seems to be a necessary condition for the existence of HEIs, I will apply the risk assessment of a selected HEI to determine the expected outcome of this risk. For the purpose of this exercise, I have selected the recently revised risk assessment instrument of the University of South Africa (Unisa). This HEI developed and approved the first version of its enterprise risk management framework in 2006 (Unisa 
2014:1). This framework was frequently revised and aligned with the South African National Standard Risk Management Principles and Guidelines (SANS 31000:2009) as well as with the King III Report on Corporate Governance (2009) (Unisa 2014:1). This framework includes an instrument for assessing and managing risks in the institution in order to exclude "the possibility of the uncertain" to which Dupuy (2008:5) refers. This assessment instrument provides for the measuring of two dimensions of risks, namely the consequence of the risk (see the columns of Table 2) and the likelihood (the rows of Table 3) that it will occur (Unisa 2014:27-29). The risk of the specific risk category for the institution is determined by multiplying the values attached respectively to the consequence and the likelihood of the particular risk category. The numerical result is plotted on the risk heat map indicated in the numerical values and colours in Tables 2 and 3 .

The first row in Table 2 presents the general descriptions of each of the four degrees of consequences as indicated in the separate columns. The additional rows in the selected institution's official consequence rating table contain descriptions for the various degrees of consequences for each of the following (known) categories of risks consequences: Strategic Objectives, Teaching and Learning, Research, Community Engagement, Safety \& Environment, Financial, Reputation, Compliance and Stakeholders. Academic staff, not to mention the "human spirit", is evidently not an official (known) category of risk for the rating of the consequence in the institution's Enterprise Risk Management Framework, but for the particular institution, a risk category within "the realm of uncertainty" (Dupuy 2008:5). My application of this institution's risk assessment instrument to the "caring human spirit" as a risk category is thus an attempt to adapt this instrument eventually by including "caring human spirit" as an additional risk category in order to "properly gauge the type of uncertainty with which we are confronted at present" (Dupuy 2008:5).

The likelihood rating scale (as indicated in the various rows of Table 3) measures the probability that the risk will materialise, and provides for four factors on a scale ranging from low, through moderate and high, to very high. For the purpose of assessing the consequence and the likelihood of that risk, I have used an adjusted version of the selected institution's risk assessment instrument for developing Tables 2 and 3 (Unisa 2014:Annexures 1 \& 2). By combining the consequence and the likelihood of the particular risk in a matrix, the results of the risk assessment can be calculated and plotted on a heat map (Table 4).

The logical implication (consequence) of the proposition that a caring human spirit is a necessary condition for the HEIs to fulfil their reason for existence is that HEIs cannot fulfil their reason for existence in the absence a caring human spirit. The exact effect of the absence of a caring human spirit on the objectives of HEIs (see Purdy 2010:882) is that uncertainty to be calculated by means of the consequence rating scale (Table 2). The consequence of this risk may be rated on a continuum between "Very high" and "Low". For that purpose, the inclusion of the following descriptors of the four consequence factors (see Unisa 2014:Annexure 1) for this additional institutional risk category is suggested:

Very high (factor 4): This factor constitutes a complete absence of an independent, communitarian caring human spirit (Weinberg \& Graham-Smith 2012:68). This absence is evident from an inability of academic staff to "engage practically in the awkward, messy, joyful and risky work of thinking and acting differently" (Amsler 2011). It is also evident from an inability of staff to take care, pay attention and maintain care of themselves, others, and knowledge (Stiegler 2010:179). This factor of consequence will have a detrimental long- 
term effect on the institution by leaving it without a reason for existence. The consequence of this risk is thus the closure of the university as currently constituted.

High (factor 3): A high consequence factor constitutes a constantly reduced independent, communitarian (Weinberg \& Graham-Smith 2012:68) caring human spirit. This is evident from an inability of academic staff to engage in critical and rigorous discourse (Amsler 2011) and to care for people and knowledge (Stiegler 2010:179). In addition to this reduced critical and rigorous discourse, Morin (2007:21) refers to another risk, namely the risks of disciplines "hermetically closing off a knowledge that could be useful to all of us". Furthermore, disempowered academics at middle management level, experiencing "a culture of conformance over collegiality, control at the cost of innovation and experimentation, and an over-articulation of strategy" devaluate the institution's mission (Davis et al. 2014). The consequence of this risk thus is a prolonged negative effect on the university's ability to fulfil its reason for existence.

Moderate (Factor 2): A moderate risk consequence constitutes inadequately qualified academics with consequently restricted abilities for contributing to new knowledge, encountering the unknown and critically confronting the undetermined future (South Africa 2014:3-6; Stiegler 2010:179). Furthermore, the burnout of academic staff has a detrimental effect on their ability to care for people and for knowledge (Stiegler 2010:179). It is possible to manage these consequences by actively taking care of those factors smothering the human spirit of academic staff members "under normal operating conditions" (Unisa 2014:Annexure 1).

Low (Factor 1): A low risk consequence constitutes adequately qualified young academic staff members, who lack the spirit of guiding and inspiring "humans towards many great achievements" (De Beer 2013:498). Morin (2007:21) refers in this regard to "the risk of superficial talkativeness". Provided this risk is limited to only a small percentage of the academic staff members at an HEI, it may be possible to readily absorb the consequences of such a risk under normal operating conditions.

If one compares the evidence of a constantly reduced independence and collegiality, a simultaneously increased culture of conformance and control, and symptoms of burnout from the three selected articles with the above consequence rating scale, it is evident that, for HEIs, the consequence rating of the risk of a smothered caring human spirit is high (factor 3 ) to very high (factor 4$)$.

The likelihood rating is a crucial dimension of the assessment of the risk of a smothered caring human spirit to HEIs, as this relates directly to what Beck (2000:214) calls the power of the non-existent, constructed and fictitious future to have an effect on the present. The likelihood assessment of a smothered caring human spirit as a risk to HEIs is thus a considered perception of the power of possibly "non-existent, constructed and fictitious threats" to influence the future (Beck 2000:214). 
Table 2: The consequences of the risk to HEIs of a smothered caring human spirit

\begin{tabular}{|c|c|c|c|c|}
\hline \multirow[b]{2}{*}{ 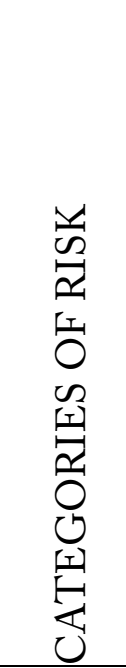 } & \multicolumn{4}{|c|}{ FACTOR OF CONSEQUENCES } \\
\hline & $\begin{array}{l}\text { Very high } \\
(4) \\
\text { Disruption to } \\
\text { service; university } \\
\text { closure. } \\
\text { Fundamental to } \\
\text { institutional } \\
\text { objectives. }\end{array}$ & $\begin{array}{l}\text { High } \\
\text { (3) } \\
\text { Critical event, } \\
\text { which can be } \\
\text { endured but may } \\
\text { have a prolonged } \\
\text { negative effect and } \\
\text { extensive } \\
\text { consequences. }\end{array}$ & $\begin{array}{l}\text { Moderate } \\
\text { (2) } \\
\text { Can be managed } \\
\text { under normal } \\
\text { operating } \\
\text { conditions. Brief } \\
\text { local } \\
\text { inconvenience } \\
\text { (work around). } \\
\text { Loss of an asset } \\
\text { with minor } \\
\text { influence on } \\
\text { operations. }\end{array}$ & $\begin{array}{l}\text { Low } \\
(1) \\
\text { Consequences can } \\
\text { be readily absorbed } \\
\text { under normal } \\
\text { operating } \\
\text { conditions. } \\
\text { No business } \\
\text { disruptions. }\end{array}$ \\
\hline $\begin{array}{l}\text { Caring } \\
\text { human } \\
\text { spirit }\end{array}$ & $\begin{array}{l}\text { Absence of } \\
\text { independent, } \\
\text { communitarian } \\
\text { caring human } \\
\text { spirit; inability to } \\
\text { engage in the work } \\
\text { of thinking and } \\
\text { acting differently; } \\
\text { inability to take } \\
\text { care, pay attention } \\
\text { and take care of } \\
\text { themselves, others, } \\
\text { and knowledge; } \\
\text { leaving institution } \\
\text { without a reason } \\
\text { for existence. } \\
\text { Consequence: } \\
\text { closure of the } \\
\text { university. }\end{array}$ & $\begin{array}{l}\text { Disempowered } \\
\text { academics at } \\
\text { middle } \\
\text { management level; } \\
\text { conformance over } \\
\text { collegiality; control } \\
\text { at the cost of } \\
\text { innovation and } \\
\text { experimentation; } \\
\text { devaluating the } \\
\text { institution's } \\
\text { mission. } \\
\text { Consequence: a } \\
\text { prolonged negative } \\
\text { effect on the } \\
\text { university's ability } \\
\text { to fulfil its reason } \\
\text { for existence. }\end{array}$ & $\begin{array}{l}\text { Restricted abilities } \\
\text { for contributing to } \\
\text { new knowledge, } \\
\text { encountering the } \\
\text { unknown and } \\
\text { critically confront } \\
\text { the undetermined } \\
\text { future; burnout of } \\
\text { academic staff } \\
\text { with inability to } \\
\text { take care, pay } \\
\text { attention and take } \\
\text { care of themselves, } \\
\text { others, and } \\
\text { knowledge. } \\
\text { Possible to manage } \\
\text { by actively taking } \\
\text { care of those } \\
\text { smothering factors }\end{array}$ & $\begin{array}{l}\text { Lack of the spirit } \\
\text { guiding and } \\
\text { inspiring "humans } \\
\text { towards many } \\
\text { great } \\
\text { achievements". } \\
\text { Readily absorb the } \\
\text { consequences of } \\
\text { such a risk under } \\
\text { normal operating } \\
\text { conditions through } \\
\text { e.g. mentorship. }\end{array}$ \\
\hline$\pi$ & & & & \\
\hline
\end{tabular}

\# The other possible categories of risk may be the following: Strategic objectives; Teaching and learning; Research; Community engagement; Information Communication Technology (ICT); Safety and environmental; Financial; Reputation; Compliance; Stakeholders. 
As a smothered caring human spirit is evidently not a hypothetical or unknown risk, the likelihood rating is thus an effort to quantify this risk "in terms of objective probabilities based on observable frequencies" (Dupuy 2008:5). The risk assessment instrument (Table 3) provides for the following scale descriptors of likelihood (Unisa 2014:Annexure 2) to determine the effect of the uncertainty:

Table 3: The likelihood of risk to HEIs of a smothered caring human spirit

\begin{tabular}{|l|l|l|l|l|}
\hline $\begin{array}{l}\text { Likelihood } \\
\text { scale }\end{array}$ & Factor & General description & $\begin{array}{l}\text { Chances of } \\
\text { occurrence }\end{array}$ & Probability \\
\hline Very high & 4 & $\begin{array}{l}\text { Expected to occur in most } \\
\text { circumstances } \\
\text { Can be difficult to control due to } \\
\text { external influences }\end{array}$ & $\begin{array}{l}\text { Could occur } \\
\text { multiple times in } 18 \\
\text { months, and/or } \\
\text { Has occurred in the } \\
\text { last 12 months }\end{array}$ & 81\% or more \\
\hline High & 3 & $\begin{array}{l}\text { History of occurrence in the } \\
\text { university } \\
\text { More than an even chance of } \\
\text { occurring }\end{array}$ & $\begin{array}{l}\text { Could occur once in } \\
18 \text { months, and/or } \\
\text { Has occurred in the } \\
\text { last 24 months }\end{array}$ & 41-80\% \\
\hline Moderate & 2 & $\begin{array}{l}\text { Would be expected when it occurs } \\
\text { Low }\end{array}$ & $\begin{array}{l}\text { Could occur at least } \\
\text { once in 24 months, } \\
\text { and/or } \\
\text { Has occurred in the } \\
\text { last 36 months }\end{array}$ & $21-40 \%$ \\
\hline & $\begin{array}{l}\text { May only occur in exceptional } \\
\text { circumstances } \\
\text { Would be unexpected when it } \\
\text { occurs }\end{array}$ & $\begin{array}{l}\text { Could occur in 36 } \\
\text { months or more, } \\
\text { and/or } \\
\text { Has either never } \\
\text { occurred or it } \\
\text { occurred in the last } \\
\text { 5 years. }\end{array}$ & 0-20\% \\
\hline
\end{tabular}

Very high (4): There is a very high likelihood of risks expected to occur in most circumstances. They are often difficult to control due to external influences (Unisa 2014:Annexure 3).

High (3): There is a high likelihood of risks with an expected frequency determined from past experiences (e.g. the history of the university) with the potential to influence the future (Beck 2000:214) and risks have a more than even chance of occurring.

Moderate (2): Risks of a moderate nature is described as those to be expected with a less than even chance of them occurring (Unisa 2014:Annexure 3).

Low (1): Low risks may only occur in exceptional circumstances, and if they would occur, it would be unexpected (Unisa 2014:Annexure 3). 


\section{Table 4: Risk heat map of the assessment of the risk of a smothered caring human spirit for HEIs}

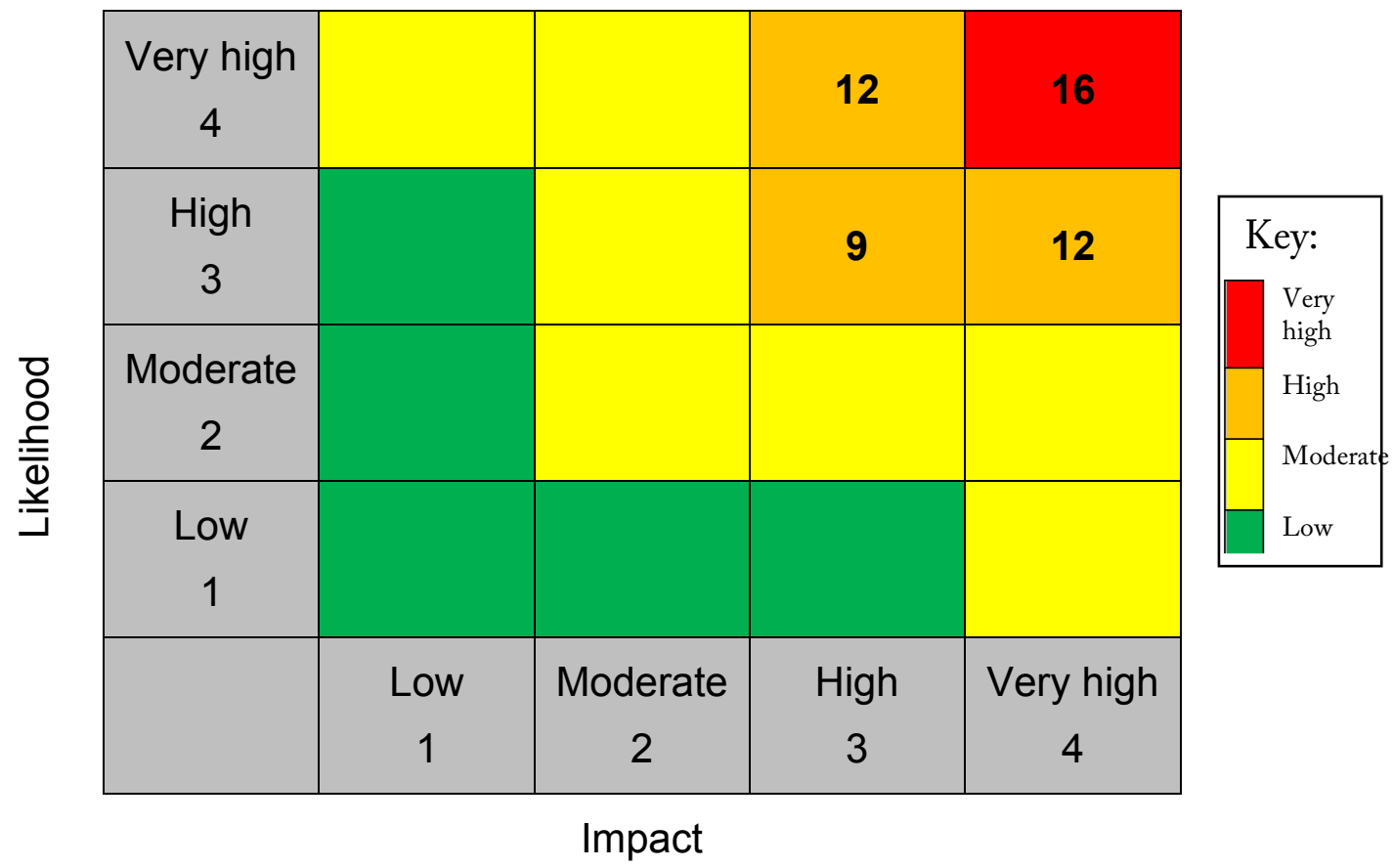

In the light of the concerns of Amsler (2011:62-87), Weinberg and Graham-Smith (2012:68, 73--74), Roux (2012:34) and Davis et al. (2014), based on their thorough review of recent literature and trends regarding the effect of a growing culture of managerialism on what is referred to in this article as a "caring human spirit in HEIs", there are adequate reasons to suspect that the likelihood of a caring human spirit being smothered or in danger of disappearance in HEIs, may be high (factor 3) or even very high (factor 4). This conclusion is also supported by the findings of an empirical study by Rothman and Barkhuizen (2008:439-456),

If one integrates the above consequence ( 3 to 4 ) and likelihood (3 to 4 ) ratings of the risk of a smothered caring human spirit to HEIs in a final assessment of the scope of this risk for HEIs, it seems that, on a scale from 1 to 16, the risk varies between 9 and 16. On the risk heat map (Table 4), the risk is shown to be high to very high. This rating will vary among HEIs and the organisational units within them. However, there is ample reason for sincere concern about the high rating of an actual risk not included in the list of risk categories in the selected institution's risk management framework.

\section{Conclusion}

With this article, I made an attempt to contribute to the continuing discourse on both risk management and managerialism in higher education. I have focused specifically on the risk of a smothered human spirit for HEIs. The thesis for this article was that a caring human spirit is a necessary condition for HEIs to fulfil their reason for existence. The implication of this thesis is that the absence of a caring human spirit in HEIs is supposed to be regarded as an actual risk for these institutions. The purpose of this article was thus to reflect on this implication and the risk of HEIs not being able to fulfil their fundamental reason for existence. 
Following the discourse on risk and risk management, I have used the concept 'risk' to refer to those uncertain future events that may influence HEIs' plans and actions for achieving their primary reason for existence. A reproductive and hermeneutical reading of official and scholarly texts showed that HEIs' primary reason for existence is an embedded risk, namely a concern with the new and the unknown and, by implication, a critical curiosity about an uncertain future. HEIs thus need academic staff members who are caring human spirits with the necessary knowledge, habits and behaviour, making them professional scholars who care not only for the 'what' of knowledge, but especially for the 'how' and the 'why'. Within the South African context, it is specifically a care for those essential issues leading to relevant science (De Beer (1991:100). Caring human spirits are thus necessary for HEIs' endeavour of seeking, understanding, demystifying, transforming, educating, paying attention, and enhancing social mobility.

The caring human spirit has been shown not only to be a necessary condition for HEIs fulfilling the reason for their existence, but also to be a crucial risk category currently absent from the standard list of institutional risk categories. An assessment of the risk of the absence of a caring human spirit in HEIs for those institutions reveals the risk for the HEI as being high to very high. A caring human spirit is thus a necessary condition for HEIs to fulfil their reason for existence. A smothered caring human spirit has been shown to pose a high to very high risk to the survival of HEIs. Considering Beck's (2000:214) view on the effect of risk (being part of a "fictitious future") on the present, one can argue that the consequence and likelihood of a smothered or absent caring human spirit in future, is "something that projects its shadow onto the present" (Beck 2000:214). If HEIs regard this risk as not real, fictitious or only hypothetical, Beck (2000:214) is perhaps correct when he states, "there is nothing in it that we should fear". This article has argued that the likelihood of a smothered or absent human spirit in HEIs is not only real but indeed also high to very high. With an equally high rating for the consequence of such a risk, the risk of a smothered caring human spirit for HEIs may be detrimental for the future of these institutions. How this risk is managed and mitigated, will determine whether HEIs are protected or endangered.

\section{List of sources}

Adam, B., Beck, U and Van Loon, J. 2000. Introduction: Repositioning Risk; the Challenge for Social Theory. In The Risk Society and Beyond: Critical Issues for Social Theory edited by Adam, B, Beck, U and Van Loon, J. 2000. London: SAGE.

Adam, B. 1998. Timescapes of modernity: The environment and invisible hazards. London: Routledge.

Adam, B. 2008. Environmental Timescapes of Modernity: Conceptual Challenges. Presentation to Social Theory Forum Environmental Society Theory, Cardiff University, SOCSI, 10 December 2008. Available online at: http://www.cf.ac.uk/socsi/resources/Soc\%20Th\%20Forum\%20Talk\%203\%20101208. pdf.

Adam, B, Beck, U and Van Loon, J. 2000. The Risk Society and Beyond: Critical issues for Social Theory. London: SAGE.

Adams, J. 1995. Risk. London: UCL Press. 
Amsler, S. 2011. Beyond All Reason: Spaces of Hope in the Struggle for England's Universities. Representations, 116(1):62-87

Andretta, M. 2014. Some Considerations on the Definition of Risk Based on Concepts of System Theory and Probability. Risk Analysis, 34(7):1184-1195.

Ariff, M.S.B.M., Zakuan, N, Tujadin, M.N.M., Ahmads, A., Ishak, N. and Ismail, K. 2014. A Framework for Risk Management Practices and Organizational Performance in Higher Education. Review of Integrative Business E Economics Research, 3(2):422-432.

AGB. 2007. See: Association of Governing Boards of Universities and Colleges.

Association of Governing Boards of Universities and Colleges (AGB). 2007. Meeting the Challenges of Enterprise Risk Management in Higher Education. Washington DC: AGB. www.agb.org.

Aven, T. 2012. Foundational Issues in Risk Assessment and Risk Management. Risk Analysis, 32(10):1647-1656.

Beck, U. 1992. Risk Society: Towards a Nerw Modernity. London: SAGE.

Beck, U. 2000. Risk Society Revisited: Theory, Politics and Research Programmes. In The Risk Society and Beyond: Critical Issues for Social Theory edited by Adam, B, Beck, U and Van Loon, J. 2000. London: SAGE.

Castoriades, C. 1984. Crossroades in the labyrinth. Sussex: Harvester Press.

Council on Higher Education (CHE). 2013. A proposal for undergraduate curriculum reform in South Africa: The case for a flexible curriculum structure. Report of the Task Team on Undergraduate Curriculum Structure. Discussion Document. August 2013. Pretoria: Council on Higher Education

Davis, A., Jansen van Rensburg, M. and Venter, P. 2014. The impact of managerialism on the strategy work of university middle managers. Studies in Higher Education, Available online at: http://dx.doi.org/10.1080/03075079.2014.981518

De Beer, C.S. 1991. Wetenskap en gewete: Enkele filosofiese perspektiewe. Pretoria: Human Sciences Research Council.

De Beer, F. 2013. Wat het intussen van die gees geword? Enkele oefeninge in die onmoontlike [What is happening to spirit in the meantime? Some exercises in the impossible]. Journal of Humanities, 53(4): 497-514.

De Beer, C.S. 2014. Reading: The understanding and Invention of Meaning. In Reflective Public Administration: Context, Knowledge and Methods. Edited by Wessels, J.S., Pauw J.C. and Thani, X.C. 2014. Pretoria: University of South Africa Press.

Douglas, M. 1992. Risk and Blame: Essays in Cultural Theory. London: Routledge. http://dx.doi.org/10.4324/9780203430866.

Dupuy, J-P. 2008. Rational Choice before the Apocalypse. Anthropoetics, 13 (3):1-18.

Institute of Directors of Southern Africa. 2009. King Code of Governance 2009. Available online at: http://c.ymcdn.com/sites/www.iodsa.co.za/resource/collection/944450064F18-4335-B7FB-

7F5A8B23FB3F/King_Code_of_Governance_for_SA_2009_Updated_June_2012.pd f 
King III. 2009. See: Institute of Directors of Southern Africa.

Lash, S. 2000. Risk Culture. In The Risk Society and Beyond: Critical Issues for Social Theory edited by Adam, B, Beck, U and Van Loon, J. London: SAGE.

Leitch, M. 2010. ISO 31000:2009 - The New International Standard on Risk Management. Risk Analysis, 30(6):887-892.

McWilliam, E. 2007. Managing 'nearly reasonable' risk in the contemporary university, Studies in Higher Education, 32:3, 311-321, DOI: 10.1080/0307507070

Morin, E. 2007. Challenges of transdisciplinarity and of complexity. In Innovation and interdisciplinarity in the university. Edited by Audy, J.L.N. and Morosini, M.C. 2007. Porto Alegre: EdiPUCRS.

Morris, V.E. (Ed). 2007. URMIA White Paper: ERM in Higher Education. Bloomington, IN: University Risk Management and Insurance Association.

National Planning Commission. 2011. National Development Plan: Vision for 2030. RP270/2011. ISBN: 978-0-621.40475-3.

Purdy, G. 2010. ISO 31000:2009 - Setting a New Standard for Risk Management. Risk Analysis, 30(6): 881-886.

Rothmann, S. and Barkhuizen, N. 2008. Burnout of academic staff in South African higher education institutions. South African Journal of Higher Education, 22(2): 439-456.

Roux, A.P.J. 2012. Is wetenskap moontlik in die afwesigheid van die gees? (Is science possible in the absence of spirit?). Tydskrif vir Geesteswetenskappe, 52(1): 19-35.

Roux, A.P.J. and De Beer, C.S. 2014. Onderweg na die beste moontlike wetenskap. Stellenbosch: Sun Press.

Scheer, D., Benighaus, C., Benighaus, L., Renn, O., Gold, S., Röder, B and Böl, G-F. 2014. The Distinction Between Risk and Hazard: Understanding and Use in Stakeholder Communication. Risk Analysis, 34(7):1270-1285.

South Africa. 2013. White Paper for Post-School Education and Training: Building an Expanded, Effective and Integrated Post-school System. Pretoria: Department of Higher Education and Training. Available online at: www.dhet.gov.za.

South Africa. 2014. South African Higher Education in the 20th Year of Democracy: Context, Achievements and Key Challenges. HESA presentation to the Portfolio Committee on Higher Education and Training Cape Town, 5 March 2014. Available online at: http://www.hesa.org.za

Stiegler, B. 2010. Taking care of the youth and the generations. Stanford: Stanford University Press.

Tufano, P. 2011. Managing Risk in Higher Education. Forum for the Future of Higher Education, 54-58.

Unisa (University of South Africa). 2014. Enterprise Risk Management Framework. Unpublished institutional document. Pretoria: Department Risk and Compliance, University of South Africa.

Weinberg, A. M. and G. Graham-Smith, G. 2012): Collegiality: can it survive the corporate university? Social Dynamics: A journal of African studies, 38:1, 68-86 